\title{
PERTANGGUNGJAWABAN PIDANA TERHADAP PELAKU PENCEMARAN SUNGAI DITINJAU DARI UNDANG-UNDANG NOMOR 32 TAHUN 2009 TENTANG PERLINDUNGAN DAN PENGELOLAAN LINGKUNGAN HIDUP
}

\author{
Arnazio Aulia Lesmana, Fakultas Hukum Universitas Surabaya, email: \\ arnaziolesmana@gmail.com
}

\begin{abstract}
This article is reviews the actions that pollute the river by means of disposing of waste without a waste processing is done in advance should be accountable for criminal, other causes have been heading for the judge's ruling that sentenced only 8 (eight) months against the accused and with a fine of $\mathrm{Rp}$ $1,000,000$ (one million) which in my opinion in this case more appropriate defendant charged Article 69 paragraph (1) letter a Jo. Article 98 paragraph (1) of Law No. 32 of 2009 on the Protection and Environmental Management.
\end{abstract}

Keywords: Environment; Pollution River; Criminal Liability.

\section{PENDAHULUAN}

Sumber daya alam merupakan faktor yang utama dan penting dalam kehidupan manusia dan makhluk hidup lainnya. Sumber daya alam tersebut menjadi berguna untuk manusia ketika terdapat pemanfaatan dan eksploitasi terhadap sumber daya tersebut untuk kepentingan manusia. Oleh sebab itu pemanfaatan sumber daya alam harus digunakan sebaik mungkin dengan mempertimbangkan faktor-faktor lingkungan hidup. Lingkungan hidup itu sendiri merupakan semua benda dan kondisi yang ada dalam ruang kita tempati dan mempengaruhi kehidupan kita. Menurut batasan tersebut secara teoritis ruang yang dimaksud tidak terbatas jumlahnya. Adapun secara praktis ruang yang dimaksud selalu dibatasi menurut kebutuhan yang dapat ditentukan. (Otto Soemarwoto, 2004, h 17).

Di lingkungan hidup tertentu terutama di pinggir-pinggir sungai berdiri kegiatan usaha dan membuang limbahnya melalui sungai tersebut, sehingga lingkungan menjadi tercemar. Padahal sebagaimana ditentukan dalam Pasal $28 \mathrm{H}$ ayat (1) Undang- Undang Dasar Negara Republik Indonesia Tahun 1945 menentukan bahwa, "Setiap orang berhak hidup sejahtera lahir dan batin, bertempat tinggal, dan mendapatkan lingkungan hidup yang baik dan sehat serta berhak memperoleh pelayanan kesehatan", yang berarti bahwa lingkungan hidup yang baik dan sehat merupakan hak setiap manusia. Mengenai lingkungan hidup, diatur dalam Undang-Undang Republik Indonesia Nomor 32 Tahun 2009 Tentang Perlindungan dan Pengelolaan Lingkungan Hidup (selanjutnya disingkat UU No. 32 Tahun 2009), yang diundangkan dengan pertimbangan bahwa lingkungan hidup yang baik dan sehat merupakan hak asasi setiap warga negara Indonesia.

Kualitas lingkungan hidup yang semakin menurun telah mengancam kelangsungan kehidupan manusia dan makhluk hidup lainnya sehingga perlu dilakukan perlindungan dan 
pengelolaan lingkungan hidup yang sungguh-sungguh dan konsisten oleh semua pemangku kepentingan, sebagaimana Konsideran Bagian Menimbang UU No. 32 Tahun 2009. Lingkungan hidup menurut Pasal 1 angka 1 UU No. 32 Tahun 2009 adalah "kesatuan ruang dengan semua benda, daya, keadaan, dan makhluk hidup, termasuk manusia dan perilakunya, yang mempengaruhi alam itu sendiri, kelangsungan perikehidupan, dan kesejahteraan manusia serta makhluk hidup lain". Setiap kegiatan usaha dilarang berakibat terjadinya pencemaran lingkungan. Berdasarkan Pasal 1 angka 14 UU No. 32 Tahun 2009 pencemaran adalah masuk atau dimasukkannya makhluk hidup, zat, energi, dan/atau komponen lain ke dalam lingkungan hidup oleh kegiatan manusia sehingga melampaui baku mutu lingkungan hidup yang telah ditetapkan. Hal ini berarti bahwa jika baku mutu lingkungan hidup telah terlampaui maka yang terjadi adalah adanya pencemaran lingkungan.

Di dalam Pasal 20 UU No. 32 Tahun 2009 disebutkan bahwa penentuan terjadinya pencemaran lingkungan hidup diukur melalui baku mutu lingkungan hidup. Baku mutu lingkungan hidup salah satunya meliputi baku mutu air. Larangan pencemaran baku mutu air tersebut disertai dengan suatu sanksi sebagaimana Pasal 98 ayat (1) UU No. 32 Tahun 2009, yang menentukan:

"Setiap orang yang dengan sengaja melakukan perbuatan yang mengakibatkan dilampauinya baku mutu udara ambien, baku mutu air, baku mutu air laut, atau kriteria baku kerusakan lingkungan hidup, dipidana dengan pidana penjara paling singkat 3 (tiga) Tahun dan paling lama 10 (sepuluh) Tahun dan denda paling sedikit Rp3.000.000.000,00 (tiga miliar rupiah) dan paling banyak Rp 10.000.000.000,00 (sepuluh miliar rupiah)".

Larangan disertai sanksi sebagaimana Pasal 100 ayat (1) UU No. 32 Tahun 2009, yang menentukan: "Setiap orang yang melanggar baku mutu air limbah, baku mutu emisi, atau baku mutu gangguan dipidana, dengan pidana penjara paling lama 3 (tiga) Tahun dan denda paling banyak Rp 3.000.000.000,00 (tiga miliar rupiah)". Demikian halnya dengan Pasal 104 UU No. 32 Tahun 2009, yang menentukan: "Setiap orang yang melakukan dumping limbah dan/atau bahan ke media lingkungan hidup tanpa izin sebagaimana dimaksud dalam Pasal 60, dipidana dengan pidana penjara paling lama 3 (tiga) Tahun dan denda paling banyak Rp3.000.000.000,00 (tiga miliar rupiah)".

Pencemaran lingkungan terjadi dan dilakukan oleh SU selaku Direktur CV. Pasific Harvest bertindak untuk dan atas nama perusahaan, pada hari Selasa tanggal 15 Maret 2011, bertempat di Pabrik CV. Pasific Harvest Jl. Tratas No. 61 Desa Kedungrejo Kecamatan Muncar Kabupaten Banyuwangi, ditangkap polisi atas dasar melakukan perbuatan yang melanggar baku mutu air limbah, baku mutu emisi, atau baku mutu gangguan, perbuatan mana dilakukan dengan cara-cara sebagai berikut:

Awalnya Petugas kepolisian datang ke CV. Pasific Harvest dan melakukan pengecekan di lokasi CV Pasific Harvest, Petugas melihat perlakuan limbah cair yang diberi ikan dari proses pencucian ikan yang bercampur dengan darah ikan dan langsung dibuang melalui saluran pembuangan tanpa dilakukan pengolahan di unit Instalasi Pengolahan Air Limbah (IPAL) terlebih dahulu. Selain itu, pencucian alat masak untuk bumbu saos langsung dibuang ke saluran pembuangan yang berada di Utara Pabrik di bawah jembatan (Sungai Tratas yang bermuara ke perairan Selat Bali). Pembuangan limbah cair tanpa izin yang sah tanpa melalui proses IPAL yang benar dan melebih baku mutu yang berasal dari proses produksi CV Pasific Harvest yang keluar dari saluran pembuangan luar dan dalam yang kemudian menuju Sungai Tratas yang bermuara ke Perairan Selat Bali.

Berdasarkan Surat Peringatan I yang diberikan Bupati Banyuwangi Nomor 660/025/429.023/2006 tanggal 16 Januari 2006, Surat Peringatan II Nomor 660/259/429.023/2006 tanggal 29 Mei 2006, dan Surat Perintah Perbaikan Pengelolaan Lingkungan dari Sekda Banyuwangi Nomor 660/5858/429.023/2008 tanggal 15 Agustus 2008 kepada CV. Pasific Harvest, terdakwa selaku Direktur CV Pasific Harvest sudah mengetahui kewajiban untuk mengolah limbah air tersebut, namun kewajiban tersebut tidak dilaksanakan. 
Selain itu diketahui bahwa pengolahan khusus Limbah(IPAL) tidak ada/gudang dibangun tetapi belum ada mesinnya sehingga belum dapat difungsikan, bahwa warna Air Limbah CV Pasifik Harvest adalah merah darah campur sisik ikan. Selajuntnya, sampel tersebut dikirim ke Laboratorium untuk diteliti; bahwa hasilnya melebihi baku mutu air. SU selaku Direktur CV. Pasific Harvest telah mengetahui bahwa hasil pengolahan limbahnya melebihi ambang batas baku mutu yang ditentukan dan proses pembuangan limbah industri CV. Pasifik Harvest yang dibuang ke media lingkungan tanpa melalui proses pengolahan IPAL yang benar. Jaksa Penuntut Umum dalam surat dakwaannya mendakwa SU dalam dakwaan kesatu telah melakukan perbuatan sebagaimana diatur dalam Pasal 100 ayat (1) UU No. 32 Tahun 2009 tentang Perlindungan dan Pengelolaan Lingkungan Hidup atau dakwaan kedua Jaksa Penuntut Umum mendakwa SU melakukan perbuatan Perbuatan sebagaimana diatur dalam Pasal 104 UU Nomor 32 Tahun 2009.

Pengadilan Negeri Banyuwangi dalam putusannya Nomor: 410/Pid.B/ 2012/PN.Bwi, amarnya menyatakan SU, telah terbukti secara sah dan meyakinkan bersalah melakukan tindak pidana Dumping limbah ke media lingkungan hidup tanpa ijin. Dalam hal ini SU dijatuhkan pidana kepada penjara selama 8 (Delapan) Bulan, dan denda sebesar Rp 1.000.000,- (Satu juta rupiah). Hukuman tersebut tidak perlu dijalankan, kecuali dalam tenggang waktu selama 10 (Sepuluh) Bulan terdakwa telah melakukan perbuatan pidana yang dapat dihukum berdasarkan putusan Hakim yang mempunyai kekuatan hukum yang tetap.

Penelitian ini bertujuan untuk mengetahui pertanggungjawaban pidana terhadap pelaku pencemaran sungai yang ditinjau berdasarkan Undang-Undang Nomor 32 Tahun 2009 tentang Perlindungan dan Pengelolaan Lingkungan Hidup.

\section{Pembahasan}

Pemerintah Republik Indonesia mengundangkan Undang-Undang Republik Indonesia Nomor 32 Tahun 2009 tentang Perlindungan dan Pengelolaan Lingkungan Hidup, mengingat Negara Republik Indonesia adalah negara berdasar atas hukum, maka negara, pemerintah, dan seluruh pemangku kepentingan berkewajiban untuk melakukan perlindungan dan pengelolaan lingkungan hidup dalam pelaksanaan pembangungan berkelanjutan agar lingkungan hidup Indonesia dapat tetap menjadi sumber dan penunjang agar lingkungan hidup Indonesia dapat tetap menjadi sumber dan penunjang hidup bagi rakyat Indonesia serta makhluk hidup lain. Berkaitan dengan Perlindungan dan Pengelolaan Lingkungan Hidup maka dalam pembuangan dan pengelolaan limbah hasil produksi pabrik tentu harus memenuhi ketentuan pengelolaan limbah sesuai dengan amanat Undang-Undang Republik Indonesia Nomor 32 Tahun 2009 tentang Perlindungan dan Pengelolaan Lingkungan Hidup agar menjamin kepastian hukum bagi usaha pengelolaan dan semua pemangku kepentingan tersebut agar tidak terjadinya pencemaran atau perusakan lingkungan hidup.

Pencemaran lingkungan hidup adalah masuk atau dimasukkannya makhluk hidup, zat, energi, dan/atau komponen lain ke dalam lingkungan hidup oleh kegiatan manusia sehingga melampaui baku mutu lingkungan hidup yang telah ditetapkan, pengertian pencemeran lingkunagn hidup tersebut diatur dalam ketentuan Pasal 1 angka 14 UU No. 32 Tahun 2009. Perusakan lingkungan hidup diatur dalam ketentuan Pasal 1 angka 16 UU No. 32 Tahun 2009, yang menentukan bahwa: "perusakan lingkungan adalah tindakan yang menimbulkan perubahan langsung atau tidak langsung terhadap sifat fisik dan/atau hayatinya yang mengakibatkan lingkungan hidup tidak berfungsi lagi". Pencemaran lingkungan menurut Arief Nur Du'a dikategorikan menjadi 3 (tiga), yaitu:

a) Pencemaran air, yakni suatu perubahan keadaan di suatu tempat penampungan air seperti danau, sungai, lautan dan air akibat aktivitas manusia. Pencemaran air dapat disebabkan oleh berbagai hal dan memiliki karakteristik yang berbeda-beda;

b) Pencemaran tanah, yakni di mana bahan kimia buatan manusia masuk dan merubah lingkungan tanah alami. Pencemaran ini biasanya terjadi karena kebocoran limbah cair atau 
bahan kimia industri. Ketika suatu zat berbahaya/beracun telah mencemari permukaan tanah, maka dapat menguap, tersapu air hujan dan/atau masuk ke dalam tanah, pencemaran yang masuk ke dalam tanah kemudian terendap sebagai zat kimia beracun di tanah. Zat beracun tersebut dapat berdampak langsung kepada manusia ketika bersentuhan atau dapat mencemari air tanah dan udara di atasnya;

c) Pencemaran udara, yakni penyimpangan dari kondisi normal, bertambahnya kadar atau konsentrasi unsur tertentu atau masuknya unsur/ikatan kimia lain yang merubah kualitas udara sehingga merugikan lingkungan (Arief Nurdu'a:1993 h 39).

Pencemaran udara menurut Arief Nur Du'a terbagi menjadi 2 (dua) kategori yaitu: (1) Pencemaran udara sekunder terbentuk dari reaksi pencemaran-pencemaran primer di atmosfer seperti pertumbuhan efek dari emisi polusi udara, pemanasan global, perubahan iklim yang semakin meningkat; (2) Pencemaran udara primer ditimbulkan langsung dari sumber pencemaran udara, contohnya karbon monoksida yang merupakan hasil dari pembakaran, seperti pembakaran batu bara, pembakaran hutan, membakar kebun, bahan bakar minyak dan pembakaran lainnya yang mempunyai limbah berupa partikular (aerosol, debu, abu terbang, kabut, asap, dan jelaga), kegiatan pabrik yang berhubungan dengan pemulasan, penghancuran benda keras, kegiatan pembongkaran dan pembukaan lahan harus selalu mematuhi aturan hukum sebagaimana yang telah diatur dalam Undang- Undang (Arief Nurdu'a:1993). Pelaksanaan hukum perlindungan dan pengelolaan lingkungan hidup dalam prakteknya harus sesuai dengan undang-undang dan harus memperhatikan beberapa asas peraturan perundang-undangan, antara lain:

a. Asas tanggung jawab Negara adalah negara menjamin pemanfaatan sumber daya alam akan memberikan manfaat yang sebesar-besarnya bagi kesejahteraan dan mutu hidup rakyat, baik generasi masa kini maupun generasi masa depan;

b. Asas kelestarian dan keberlanjutan adalah bahwa setiap orang memikul kewajiban dan tanggung jawab terhadap generasi mendatang dan terhadap sesamanya dalam satu generasi dengan melakukan upaya pelestarian daya dukung ekosistem dan memperbaiki kualitas lingkungan hidup;

c. Asas keserasian dan keseimbangan adalah bahwa pemanfaatan lingkungan hidup harus memperhatikan berbagai aspek seperti kepentingan ekonomi, sosial, budaya, dan perlindungan serta pelestarian ekosistem;

d. Asas keterpaduan adalah bahwa perlindungan dan pengelolaan lingkungan hidup dilakukan dengan memadukan berbagai unsur atau menyinergikan berbagai komponen terkait;

e. Asas manfaat adalah bahwa segala usaha dan/atau kegiatan pembangunan yang dilaksanakan disesuaikan dengan potensi sumber daya alam dan lingkungan hidup untuk peningkatan kesejahteraan masyarakat dan harkat manusia selaras dengan lingkungannya;

f. Asas kehati-hatian adalah bahwa ketidakpastian mengenai dampak suatu usaha dan/atau kegiatan karena keterbatasan penguasaan ilmu pengetahuan dan teknologi bukan merupakan alasan untuk menunda langkah-langkah meminimalisasi atau menghindari ancaman terhadap pencemaran dan/atau kerusakan lingkungan hidup;

g. Asas keadilan adalah bahwa perlindungan dan pengelolaan lingkungan hidup harus mencerminkan keadilan secara proporsional bagi setiap warga negara, baik lintas daerah, lintas generasi,maupun lintas gender;

h. Asas ekoregion adalah bahwa perlindungan dan pengelolaan lingkungan hidup harus memperhatikan karakteristik sumber daya alam, ekosistem, kondisi geografis, budaya masyarakat setempat, dan kearifan lokal;

i. Asas keanekaragaman hayati adalah bahwa perlindungan dan pengelolaan lingkungan 
hidup harus memperhatikan upaya terpadu untuk mempertahankan keberadaan, keragaman, dan keberlanjutan sumber daya alam hayati yang terdiri atas sumber daya alam nabati dan sumber daya alam hewani yang bersama dengan unsur nonhayati di sekitarnya secara keseluruhan membentuk ekosistem;

j. Asas pencemar membayar adalah bahwa setiap penanggung jawab yang usaha dan/atau kegiatannya menimbulkan pencemaran dan/atau kerusakan lingkungan hidup wajib menanggung biaya pemulihan lingkungan;

k. Asas partisipatif adalah bahwa setiap anggota masyarakat didorong untuk berperan aktif dalam proses pengambilan keputusan dan pelaksanaan perlindungan dan pengelolaan lingkungan hidup, baik secara langsung maupun tidak langsung;

1. Asas kearifan lokal adalah bahwa dalam perlindungan dan pengelolaan lingkungan hidup harus memperhatikan nilai-nilai luhur yang berlaku dalam tata kehidupan masyarakat

$\mathrm{m}$. Asas tata kelola pemerintahan yang baik adalah bahwa perlindungan dan pengelolaan lingkungan hidup dijiwai oleh prinsip partisipasi, transparansi, akuntabilitas, efisiensi, dan keadilan;

n. Asas otonomi daerah adalah bahwa Pemerintah dan pemerintah daerah mengatur dan mengurus sendiri urusan pemerintahan di bidang perlindungan dan pengelolaan lingkungan hidup dengan memperhatikan kekhususan dan keragaman daerah dalam bingkai Negara Kesatuan Republik Indonesia.

Berkaitan dengan asas peraturan perundang undangan yaitu asas kehati-hatian adalah bahwa ketidakpastian mengenai dampak suatu usaha dan/atau kegiatan karena keterbatasan penguasaan ilmu pengetahuan dan teknologi bukan merupakan alasan untuk menunda langkah-langkah meminimalisasi atau menghindari ancaman terhadap pencemaran dan/atau kerusakan lingkungan hidup.

Dalam kasus SU yang melakukan pencemaran sungai dengan membuang limbah langsung ke sungai tanpa melakukan pengolahan Limbah di IPAL terlebih dahulu maka jelas telah mengesampingkan asas kehati-hatian sehingga gagal menghindari pencemaran sebagaimana Berdasarkan Surat Peringatan I yang diberikan Bupati Banyuwangi Nomor :660/025/429/023/2006 tanggal 16 Januari 2006 yang isinya adalah tentang kewajiban pembenahan pengelolaan limbah karena sudah melampaui baku mutu air limbah dan telah mencemarkan Sungai Tratas di Kabupaten Banyuwangi. Jaksa Penuntut Umum mendakwa dengan dakwaan alternatif dimana dakwaan pertama menggunakan Pasal 100 ayat (1) UU No. 32 Tahun 2009, yang menentukan: "Setiap orang yang melanggar baku mutu air limbah, baku mutu emisi, atau baku mutu gangguan dipidana, dengan pidana penjara paling lama 3 (tiga) Tahun dan denda paling banyak Rp 3.000.000.000,00 (tiga miliar rupiah)". Atau dakwaan Kedua dengan Pasal 104 UU No. 32 Tahun 2009, yang menentukan: Setiap orang yang melakukan dumping limbah dan/atau bahan ke media lingkungan hidup tanpa izin sebagaimana dimaksud dalam Pasal 60, dipidana dengan pidana penjara paling lama 3 (tiga) Tahun dan denda paling banyak Rp3.000.000.000,00 (tiga miliar rupiah)".Penuntut Umum memberikan tuntutan pidana dengan Pasal 104 Undang- Undang Nomor 32 Tahun 2009. Maka majelis hakim mengabulkan dakwaan alternatif sesuai ketentuan Pasal 104 Undang- Undang Nomor 32 Tahun 2009. Ketentuan Pasal 104 Undang- Undang Nomor 32 Tahun 2009 tentang Perlindungan dan Pengelolaan Lingkungan Hidup menentukan bahwa "Setiap orang yang melakukan dumping limbah dan/atau bahan ke media lingkungan hidup tanpa izin sebagaimana dimaksud dalam Pasal 60, dipidana dengan pidana penjara paling lama 3 (tiga) Tahun dan denda paling banyak Rp3.000.000.000,00 (tiga miliar rupiah)".

Berdasarkan ketentuan Pasal 104 Undang- Undang Nomor 32 Tahun 2009 tentang Perlindungan dan Pengelolaan Lingkungan Hidup terdapat unsur unsur sebagai berikut:

a. Setiap orang 
b. Melakukan dumping limbah ke media lingkungan hidup

c. Tanpa izin sebgaimana dimasud dalam Pasal 60

Masing masing unsur akan dijelaskan lebih rinci sebagai berikut:

Unsur pertama "Setiap Orang" Unsur pertama" adalah "kata-kata "setiap orang atau barang siapa" sangat jelas menunujukan subjek pelaku tindak pidana yaitu" orang". (Saifullah 2007, h 135). Dimana merupakan unsur yang penting dari suatu tindak pidana karena untuk menentukan adanya suatu tindak pidana harus terdapat subyek pelaku tindak pidana yaitu orang. Unsur barang siapa dalam kasus ini adalah SU sebagai subyek pelaku tindak pidana. Maka unsur tersebut telah terpenuhi(Saifullah:2007h135).

Unsur kedua "melakukan dumping ke media lingkungan hidup" SU yang membuang limbah langsung ke sungai tanpa dilakukan pengelolahan terlebih dahulu di IPAL (Instalasi Pengolahan Air Limbah) dan SU selaku direktur operasional CV Pasifik harvest mengakui perbuatannya membuang limbah langsung ke Sungai dan mengetahui bahwa tindakannya dpat dikenakan sanksi pidana. Maka dengan demikian unsur tersebut telah terpenuhi.

Unsur ketiga "tanpa izin sebagaimana dimaksud dalama Pasal 60",SU dalam kasus ini tidak memiliki izin guna membuang limbah langsung ke media lingkungan hidup dalam hal ini adalah sungai tratas karena limbah itu sendiri belum diolah di dalam IPAL (Instalasi Pembuangan Air Limbah) dan kandungan nya telah melewati Baku Mutu Air limbah sebagaimana temuan Badan Lingkungan Hidup daerah dan Berdasarkan Surat Peringatan I yang diberikan Bupati Banyuwangi Nomor :660/025/429/023/2006 tanggal 16 Januari 2006 yang isinya adalah tentang kewajiban pembenahan pengelolaan limbah karena sudah melampaui baku mutu air limbah dan telah mencemarkan Sungai Tratas di Kabupaten Banyuwangi. Maka dengan demikian unsur tersebut telah terpenuhi.

Berkaitan dengan tindak pidana yang dilakukan oleh SU ketentuan yang lebih tepat mengatur tindak pidan tersebut ada di Pasal 98 ayat (1) Undang- Undang Nomor 32 Tahun 2009 tentang Perlindungan dan Pengelolaan Lingkungan Hidup yang menentukan: Setiap orang yang dengan sengaja melakukan perbuatan yang mengakibatkan dilampauinya baku mutu udara ambien, baku mutu air, baku mutu air laut, atau kriteria baku kerusakan lingkungan hidup, dipidana dengan pidana penjara paling singkat 3 (tiga) Tahun dan paling lama 10 (sepuluh) Tahun dan denda paling sedikit Rp3.000.000.000,00 (tiga miliar rupiah) dan paling banyak Rp 10.000.000.000,00 (sepuluh miliar rupiah).

Berdasarkan ketentuan Pasal 98 ayat (1) Undang- Undang Nomor 32 Tahun 2009 tentang Perlindungan dan Pengelolaan Lingkungan Hidup terdapat unsur unsur sebagai berikut:

a. Setiap orang

b. Dengan sengaja

c. Melakukan perbuatan sehingga dilampauinya baku mutu udara ambien, baku mutu air, baku mutu air laut, atau kriteria baku kerusakan lingkungan hidup

Masing masing unsur akan dijelaskan lebih rinci sebagai berikut:

Unsur pertama "Setiap Orang" Unsur pertama" adalah "kata-kata "setiap orang atau barang siapa" sangat jelas menunujukan subjek pelaku tindak pidana yaitu" orang". Dimana merupakan unsur yang penting dari suatu tindak pidana karena untuk menentukan adanya suatu tindak pidana harus terdapat subyek pelaku tindak pidana yaitu orang. Unsur barang siapa dalam kasus ini adalah SU selaku Direktur CV Pasific Harvest sebagai subyek pelaku tindak pidana. Maka unsur tersebut telah terpenuhi.

Unsur kedua adalah "dengan sengaja". Tindakan SU selaku Direktur CV.Pasific Harvest. yang dengan sengaja membuang limbah tanpa dilakukan pengolahan terlebih dahulu di IPAL (Instalasi Pengolahan Air Limbah) di wilayah Sungai Tratas Kabupaten Banyuwangi yang bermuara ke selat Bali. Hal ini diperkuat dengan hasil Sertifikat Hasil Pengujian No.240S/LKA-MJK/III/11 tanggal 25 
Maret 2011 didapati dengan hasil kesimpulan hasil analisa parameter tidak memenuhi Standar Peraturan Menteri Lingkungan Hidup No 0.6 Tahun 2007; serta Berdasarkan Surat Peringatan I yang diberikan Bupati Banyuwangi Nomor :660/025/429/023/2006 tanggal 16 Januari 2006, dan Surat Perintah Perbaikan Pengelolaan Lingkungan dari Sekda Banyuwangi Nomor :660/5858/429.023/2008 tanggal 15 Agustus 2008 kepada CV. Pasific Harvest, terdakwa selaku Direktur CV Pasific Harvest sudah mengetahui kewajiban untuk mengolah limbah air tersebut, namun kewajiban tersebut tidak dilaksanakan.. Tindakan SU yang melakukan pencemaran lingkungan sungai tersebut merupakan suatu kejadian yang dikehendaki oleh SU. Kesengajaan (dolus) adalah merupakan bagian dari kesalahan (schuld), kesengajaan pelaku mempunyai hubungnan kejiwaan yang lebih erat terhadap suatu tindakan (terlarang/keharusan) dibdandingkan dengan culpa. Karenanya ancaman pidana pada suatu delik jauh lebih berat apabila dilakukan dengan sengaja, dibandingkan dengan apabila dilakukan dengan kealpaan (Saifullah:2007 h135).Mengenai bentuk kesengajaan, Moeljatno menjelaskan ada tiga bentuk, yaitu:

1) Kesengajaan dengan maksud (dolus derictus), yaitu si pembuat menghendaki adanya akibat yang dilarang dari perbuatannya;

2) Kesengajaan sebagai kepastian dan keharusan, yaitu si pembuat hanya dapat mencapai tujuan dengan melakukan perbuatan lain dan perbuatan tersebut juga merukan perbuatan yang dialarang;

3) Kesengajaan sebagai kemungkinan (dolus eventualis), yaitu si pembuat mengetauhi adanya kemungkinan terjadinya tindak pidana lain, namun tidak menghalangi maksud dari si pembuat untuk melakukan perbuatannya \{Moeljatno 2000, h 191).

Tindakan SU yang melakukan pencemaran sungai dengan membuang limbah langsung ke sungai tanpa melakukan pengolahan Limbah di IPAL terlebih dahulu merupakan bentuk kesengajaan yang dilihat dari tindakan SU selaku Direktur CV. Pasific Harvest yang tidak langsung mengambil tindakan agar melakukan pembenahan pada pengelolaan limbah serta tidak membuang langsung limbah ke sungai sehingga mengakibatkan tercemarnya Sungai Tratas Kabupaten Banyuwangi. Berdasarkan uraian tersebut maka SU memenuhi unsur kesengajaan sebagai kemungkinan.

Unsur ketiga adalah dilarang melakukan perbuatan yang dapat dilampauinya baku mutu udara ambien, baku mutu air, baku mutu air laut, atau kriteria baku kerusakan lingkungan hidup. Tindakan SU yang melakukan pencemaran sungai Tratas Kabupaten Banyuwangi dengan cara membuang limbah langsung ke sungai tanpa melakukan pengolahan Limbah di IPAL terlebih dahulu yang mengakibatkan pencemaran dan/atau perusakan lingkungan hidup melanggar ketentuan Pasal 69 huruf a UU No. 32 Tahun 2009. Pengertian pencemaran lingkungan berdasarkan ketentuan Pasal 1 angka 14 UU No. 32 Tahun 2009 adalah "masuk atau dimasukkannya makhluk hidup, zat, energi, dan/atau komponen lain ke dalam lingkungan hidup oleh kegiatan manusia sehingga melampaui baku mutu lingkungan hidup yang telah ditetapkan". Tindakan SU yang memasukkan zat atau komponen lain berupa Limbah hasil pengolahan ikan tanpa melakukan pengolahan Limbah di Instalasi Pengolahan Air Limbah (IPAL) terlebih dahulu yang mengakibatkan dilampauinya Baku Mutu Air Limbah Lingkungan Hidup yang telah ditetapkan Pemerintah Kabupaten Banyuwangi. Berdasarkan penjelasan tersebut di atas maka SU memenuhi unsur pencemaran lingkungan hidup atau melakukan pencemaran udara.

\section{Kesimpulan}

Berdasarkan uraian dan pembahasan, dapat disimpulkan bahwa SU yang melakukan pencemaran sungai dengan cara membuang limbah sungai tanpa dilakukan pengolahan di Instalasi Pembuangan Air Limbah (IPAL) dapat dikenakan pertanggungjawaban secara pidana berdasarkan 
ketentuan Pasal 69 ayat (1) huruf a Jo. Pasal 98 ayat (1) Undang-Undang Nomor 32 Tahun 2009 Tentang Perlindungan dan Pengelolaan Lingkungan Hidup karena tindakan SU telah memenuhi unsur-unsur kesalahan, yaitu:

a. SU telah melakukan pencemaran lingkungan dengan cara membuang limbah ke sungai tanpa dilakukan pengolahan di Instalasi Pembuangan Air Limbah (IPAL)

b. SU adalah orang yang mampu bertanggungjawab dan tidak berada dibawah pengampuan

c. Mempunyai suatu bentuk kesalahan berupa kesengajaan. Tindakan SU merupakan bentuk kesengajaan sebagai kemungkinan. Tindakan SU yang melakukan pembuangan limbah pabrik tanpa dilakukan pengolahan di Instalasi Pembuangan Air Limbah (IPAL) merupakan bentuk kesengajaan SU tidak memiliki alasan pemaaf.

d. SU memenuhi unsur tindak pidana dalam Pasal 98 ayat (1) UU No. 32 Tahun 2009. Tindakan SU karena kesengajaanya mengakibatkan dilampauinya baku mutu air lingkungan hidup. 


\section{Daftar Referensi}

Buku:

Abdi Fuad Usfa. (2006). Pengantar Hukum Pidana , Cetakan kedua , Malang:UMM Press

Abdullah Marlang\&Rina Maryana. (2015). Hukum Konservasi Sumber Daya Alam Hayati dan Ekosistemnya. Jakarta: Mitra Wacana Media.

Arief Nurdu'a. (1993). Hukum Lingkungan, Perundang-undangan serta Berbagai Masalah dalam Penegakannya. Bandung: Citra Aditya Bakti.

Chairul Huda. (2006). Dari tiada Pidana Tanpa Kesalahan Menuju Kepada Tiada Pertanggungjawaban Pidana Tanpa Kesalahan,Cetakan Kedua. Jakarta: Prenada Media.

Leden Marpaung. (2005). Asas-Teori-Praktik Hukum Pidana Cetakan pertama . Jakarta:Sinar Grafika.

M. Husein Harun. (1992). Analisis Mengenai Dampak Lingkungan. Jakarta: Bumi Aksara.

Moeljatno. (2015). Asas-Asas Hukum Pidana Cetakan Kelima. Jakarta:Rineka Cipta.

Muhamad Erwin. (2011). Hukum Lingkungan dalam Sistem Kebijaksanaan Pembangunan Lingkungan Hidup. Bandung: Refika Aditama, Bandung.

Niniek Suparni. (1992). Pelestarian, Pengelolaan dan Penegakkan Hukum Lingkungan. Jakarta: Sinar Grafika.

Otto Soemarwoto. (2004). Ekologi lingkungan dan Pembangunan. Jakarta:Djambatan.

Peter Mahmud Marzuki (2014). Penelitian Hukum. Jakarta:Prenada Media Grup.

Saifulllah. (2007). Hukum Lingkungan Cetakan 1. Malang:UIN Malang Press.

Tim Dosen. (2013). Handout Hukum Pidana, Laboratorium Hukum Pidana. Surabaya:Fakultas Hukum Universitas Surabaya 